\title{
A MAGYAR HALTANi TÁRSASÁG MEGALAKULÁSA ÉS 2005. ÉVI MÜKÖDÉSE
}

\author{
Dr. Harka Ákos
}

\section{A SZERVEZET LÉTREJÖTTE}

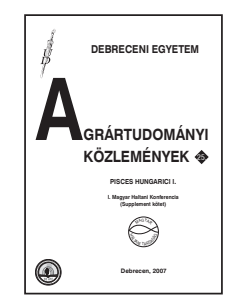

A Debreceni Egyetem Agrártudományi Centrumában 2005. szeptember 9-10-én megrendezett I. Magyar Haltani Konferencia előre beharangozott és többek által várt programpontja volt a Magyar Haltani Társaság megalakítása. Egy olyan társadalmi szervezetet kívántunk létrehozni, amelyben a természetes vizek haltani vizsgálatával foglalkozó kutatók és a téma iránt mélyebben érdeklődő szimpatizánsok együtt tevékenykedhetnek a Kárpát-medence természetes vizei és halai érdekében.

Alakuló közgyülésünkön, melyet a konferencia első programpontjaként tartottunk, 40 fő nyilvánította ki egyesületalapító szándékát. Ezt követően a társaság alapszabályának megvitatására és elfogadására került sor, majd a tisztségviselök személyéről határoztak a jelenlévők. Elnökké dr. Harka Ákost, alelnökké dr. Juhász Lajost, elnökségi taggá dr. Nagy Sándor Alexet, Sallai Zoltánt és Szepesi Zsoltot választották. November 24-én ugyan új közgyülést kellett tartanunk, ez azonban - az alapszabály egy pontjának a bíróság által elöírt módosításától eltekintve - lényegében nem változtatott a korábbi helyzeten. A Magyar Haltani Társaság hivatalos nyilvántartásba vétele december 2-án megtörtént, és az erről kiadott bírósági végzés december 21-én jogerőre emelkedett.

A megalakulást követően új jelentkezők is csatlakoztak egyesületünkhöz, így a létszámunk negyvenröl ötvenkettőre gyarapodott. Tagságunk legnépesebb csoportja az egyetemi oktatók és hallgatók köréböl kerül ki, öket követik a természetvédelem területén foglalkoztatottak, majd a kutatóintézetek munkatársai. A létszám fennmaradó mintegy 20 százaléka a közigazgatás és a közoktatás, valamint az állatgyógyászat, a halgazdálkodás és a horgászat, illetve a könyvkiadás és a könyvvizsgálat terén tevékenykedik. A legfiatalabb tagunk 17, a legidősebb 90 éves, képzettség tekintetében a maturandustól az akadémikusig terjed a skála. Szervezetünk tehát - az eredeti elképzeléseknek megfelelően - valóban nyitott mindazok számára, akik szívükön viselik természetes vizeink és halainak sorsát, jövőjét.

\section{SZAKMAI PROGRAMOK}

2005-ben két szervezeti összejövetelt tartottunk, mindkettőt szakmai program is kísérte. Gazdagabb választékot természetesen a szeptemberi alakuló üléshez kapcsolódó konferencia kínált. Tudományos ülésein elsősorban a hazai kutatók számoltak be eredményeikről, de Romániából és Szlovákiából is érkeztek előadók. A két nap során összesen 22 előadás hangzott el, és 3 posztert tekinthettek meg a résztvevők. Ezek zöme dolgozatként olvasható e kötetben, ezért még vázlatos ismertetésüktől is eltekintünk.

A második közgyülés szabad programja keretében először korelnökünket, a Széchenyi-díjas dr. Woynarovich Elek professzor urat köszöntöttük 90. születésnapja alkalmából. Gratulációnkat a Debreceni Egyetem Agrártudományi Centrumának díszoklevelével és egy személyre szóló apró ajándékkal igyekeztünk ünnepélyesebbé, ugyanakkor közvetlenebbé is tenni. Az ünnepelt professor emeritus, aki az Akadémia babérkoszorúsa (Laureatus Academiae) és két egyetemnek is tiszteletbeli doktora, rövid válaszbeszédében a természetes vizek halászatának fontosságáról szólt, majd a megemlékezést megköszönve sikeres jövőt kívánt a Magyar Haltani Társaságnak.

A szakmai beszélgetés két PowerPoint-bemutatóval kezdődött. Előbb Tóth Balázs mutatta be legújabb halunkat, a csupasztorkú gébet, ismertetve a faj hazai lelőhelyeit, fölvázolva terjedésének és ide jutásának lehetséges módjait. Ezt követően Sevcsik András adott áttekintést a Magyarországon előforduló gébfajok jellegzetességeiről, s foglalta össze az elkülönítésükre alkalmasnak tartott bélyegeket, különös tekintettel a terepmunka során történő azonosításra.

Ezt követően Sallai Zoltán élő példányokról készített fotókon mutatta be a hazai gébfajokat, majd ismertette azokat a véleményeket, amelyek vitatják, hogy az 1997-ben Bajánál fogott halpéldány Szirman-géb lenne. A jelenlévők a Szirman-géb több konzervált példányát is szemügyre vehették az előadást követően. Ezeket - a Magyar Haltani Társaság kezdeményezésére - $d r$. Vasile Otel segítségével a közelmúltban gyüjtötték a Razelmtóból, s Lengyel Péter közremüködésével kerültek Magyarországra. A referenciapéldányok és a bajai példány közti különbségek valóban jelentősek, kérdés azonban, hogy mennyire mérvadóak. A bajai példány ugyanis egy nászruhás hím, s ezek habitusa nagyon eltérhet az általános formától. Felmerült annak gyanúja is, hogy a példány egy hibrid, de a megnyugtató azonosításhoz a rokon fajok hazai populációinak, illetve a nászruhás hímeknek a biometriai vizsgálata is szükséges, ezért hosszabb időt vesz igénybe.

Befejezésül $d r$. Juhász Lajos vetített képekkel gazdagon illusztrált élménybeszámolóját hallgattuk meg a mester- 
ségesen kialakított, jósvafôi Tengerszem tó lehalászásáról. Tanulságként szolgálhat számunkra, hogy a zömmel szivárványos, kisebbrészt sebes pisztrángokkal népesített tóból a védett fürge cselle szinte teljesen eltűnt.

\section{Szervezeti élet, terveink}

Szervezetünk hatóköre az egész országra kiterjed, sőt határainkon is átnyúlik. Tagjaink három ország 15 megyéjének 34 településéről verbuválódtak. Szétszórtságunk miatt természetesen másként kell alakítani programunkat, mint az egyetlen települést érintő egyesületeknek, amelyek tagjai akár havonta összejárhatnak. Társaságunk mindössze két összejövetelt tervez évente.

Alapszabályunk rögzíti, hogy az egyesület „Évente országos szakmai tanácskozást rendez a természetes vizeinken folyó haltani kutatások eredményeinek ismertetésére és megvitatására". Ezt a tanácskozást, amelyet a legrangosabb rendezvényünknek tekintünk, visszatérő rendszerességgel az őszi időszakra tervezzük. Páros számú években tudományos ülést tartunk, a páratlan években haltani konferenciát rendezünk. Előbbin inkább csak saját tagjaink részvételére számítunk, a konferenciát szélesebb körben hirdetjük meg.

A másik, tavaszonként esedékes összejövetel megtartása jogszabály által előírt kötelezettségünk. Ugyanis az elnökségnek minden év májusáig egy közgyülés keretében kell beszámolnia a szervezet éves munkájáról és gazdálkodásáról, továbbá el kell fogadtatnia a következő évi munkatervet és költségvetést. Úgy tervezzük azonban, hogy a kötelező előírások teljesítése mellett ezekhez a találkozókhoz is mindig hozzákapcsolunk valamilyen szakmai programot, amely elősegíti egyesületi célkitűzéseink megvalósítását.

Évi egy-két találkozás kevésnek tünik ahhoz, hogy a szervezeten belül többé-kevésbé egységes közvélekedés alakuljon ki, az Internet azonban segíthet egymás gondolatainak megismerésében. Eddig ugyan inkább csak az elnök és az egyes tagok között élt ez a kapcsolat (meghívók, értesítések, tájékoztatók és hírlevelek küldése, jelentkezési lapok, adatok és kéziratok kérése, eseti levelek), az e-mail címek közzétételével azonban az egymás közötti közvetlen levélváltások mellett a körlevelek küldése is mindannyiunk számára lehetővé válik. Egyesületünk - a szétszórtság és a távolságok miatt - kvázi „levelező tagozatként” müködik a hétköznapi gyakorlatban, s ehhez érdemes igénybe venni a világháló által kínált lehetőségeket. 